\title{
Taxonomic status of grey-headed Yellow Wagtails breeding in western China
}

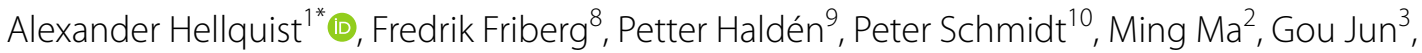 \\ Urban Olsson ${ }^{4,5}$ and Per Alström ${ }^{6,7^{*}}$
}

\begin{abstract}
Background: Field studies from 2011 onwards have demonstrated the presence of a breeding population of Yellow Wagtails (Motacilla flava) in the Xinjiang Uygur Autonomous Region, China that is phenotypically distinct from known subspecies occurring in Asia. Here we describe the plumages and vocalisations of this population and discuss its taxonomic status.

Methods: The analysis of plumage is based on field studies and photos available online. Recordings of vocalisations are compared with recordings from other Yellow Wagtail populations, and differences are analysed based on sonograms. Mitochondrial DNA from one individual is compared to other Yellow Wagtail taxa.

Results: Unlike M. flava subspecies breeding in or near Xinjiang, males in the studied population show a blue-grey head without prominent white supercilium, being most similar to the widely disjunct M. f. cinereocapilla. They differ from the similarly widely allopatric M. f. thunbergi, which might occur as a migrant or vagrant in Xinjiang, by on average cleaner yellow breast and more extensive white on the throat, and from the widely disjunct M. f. plexa and M. f. macronyx, which might also occur on migration in that area, by softer contact calls and slower pace of song. Females are similar to female M. f. feldegg in plumage. The mitochondrial ND2 tree shows the single sample from Xinjiang to be nested in the clade of western Yellow Wagtail taxa.

Conclusion: We discuss whether the Xinjiang breeding population could represent an intergrade between subspecies breeding nearby, or whether it is better regarded as a separate as yet unrecognized subspecies. We argue that the localization of its apparent range in relation to other subspecies along with fairly consistent male and female plumages suggest that it is more likely to represent an undescribed taxon, but conclude that more research is needed to firmly establish its status.
\end{abstract}

Keywords: Bioacoustics, Mitochondrial DNA, Morphology, Motacilla flava, Systematics, Undescribed populations

\section{Background}

The taxonomy of Yellow Wagtails (Motacilla flava) sensu lato is notorious, as evident by longstanding discussions on the validity and relationships of the

\footnotetext{
*Correspondence: alexander.hellquist@swedesd.uu.se; per.alstrom@ebc.uu.se ${ }^{1}$ Fatburs kvarngata 17, 11864 Stockholm, Sweden

${ }^{6}$ Animal Ecology, Department of Ecology and Genetics, Evolutionary Biology Centre, Uppsala University, Norbyvägen 18D, 75236 Uppsala, Sweden

Full list of author information is available at the end of the article
}

numerous subspecies [see Alström and Mild (2003) for a review], and the complex is often separated into two species, Western Yellow Wagtail (M. flava) sensu stricto and Eastern Yellow Wagtail (M. tschutschensis) (e.g., del Hoyo and Collar 2016; Gill et al. 2021). Despite an extensive literature on the subject, future discoveries and revisions are likely as birds in less known parts of the range are studied in more detail, and as more genetic data is published (see e.g. Ödeen and Alström 2001; Alström and Ödeen 2002; Voelker 2002; Ödeen and Björklund 2003; Pavlova et al. 2003; Drovetski et al. original author(s) and the source, provide a link to the Creative Commons licence, and indicate if changes were made. The images or other third party material in this article are included in the article's Creative Commons licence, unless indicated otherwise in a credit line to the material. If material is not included in the article's Creative Commons licence and your intended use is not permitted by statutory regulation or exceeds the permitted use, you will need to obtain permission directly from the copyright holder. To view a copy of this licence, visit http://creativecommons.org/licenses/by/4.0/. The Creative Commons Public Domain Dedication waiver (http://creativeco mmons.org/publicdomain/zero/1.0/) applies to the data made available in this article, unless otherwise stated in a credit line to the data. 
2018; Harris et al. 2018). Based on the discordance between mitochondrial and nuclear genetic data identified by Alström and Ödeen (2002), Drovetski et al. (2018) and Harris et al. (2018), and the overall slight nuclear genetic divergence, we chose in this paper to tentatively not adopt the split into two separate species but instead treat all discussed forms as Yellow Wagtail Motacilla flava.

During a trip to the Xinjiang Uygur Autonomous Region, China in May 2011, AH, FF, PH, PS and MM encountered Yellow Wagtails in several areas. As expected based on distribution maps in e.g. Alström and Mild (2003), M. f. feldegg (hereafter feldegg) were found breeding in westernmost Xinjiang along the Kazakh border, and phenotypes with white supercilia matching $M . f$. zaissanensis (hereafter zaissanensis; treated as synonymous with $M . f$. tschutschensis by Alström and Mild 2003 but better regarded as a separate subspecies or an intergrade, see Hellquist 2021) were found breeding in the Altai Mountains in the northeastern part of the region.

In addition, many males with bluish-grey heads reminiscent of the subspecies $M . f$. thunbergi, $M . f$. cinereocapilla, M. f. pygmaea or M. f. macronyx (hereafter thunbergi, cinereocapilla, pygmaea and macronyx, respectively) were observed. Some of these, encountered at scattered locations in Dzungaria (i.e. Xinjiang north of the Tien Shan Mountains), behaved like migrants. However, at three sites, they appeared to be territorial (Fig. 1):

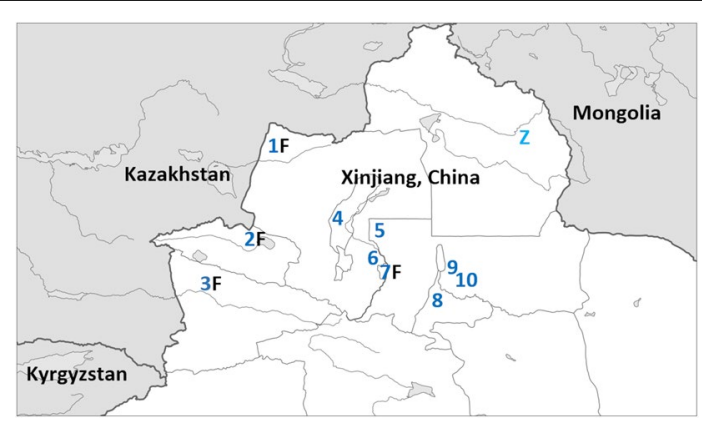

Fig. 1 Map of northern Xinjiang Uygur Autonomous Region, China and adjacent territories. Dark blue numbers mark localities mentioned in the text where grey-headed Yellow Wagtails appear to breed. 1 Jiyekexiang and Tarbagatagay. 2 Ebinur Lake. $\mathbf{3}$ Ili River Valley. 4 Karamay. 5 Mosuowan Station for Desert Research. 6 Moguhu Reservoir. 7 Shihezi. 8 Urumqi. 9 Liuyunhu. 10 Fukang. Black "Fs" mark localities where M. f. feldegg phenotypes have been observed alongside grey-headed birds. The light blue "Z" marks Kalawu Tekele Lake in the Chinese Altai $\left(47^{\circ} 01^{\prime} \mathrm{N}, 89^{\circ} 45^{\prime} \mathrm{E}\right)$, where M. f. zaissanensis phenotypes were observed breeding in 2011
- By freshwater ponds west of Ebinur Lake $\left(45^{\circ} 09^{\prime} \mathrm{N}\right.$, $\left.82^{\circ} 36^{\prime} \mathrm{E}\right)$.

- Close to the Kazakh border north of the village of Jiyekexiang $\left(46^{\circ} 28^{\prime} \mathrm{N}, 82^{\circ} 48^{\prime} \mathrm{E}\right)$.

- By a shallow lake west of the village of Liuyunhu ( $44^{\circ}$ $\left.14^{\prime} \mathrm{N}, 87^{\circ} 53^{\prime} \mathrm{E}\right)$.

Here, males with bluish-grey heads were singing from perches on wires and in tall grass or reeds. By Ebinur Lake, FF observed one bird carrying nest material. At both Ebinur Lake and Jiyekexiang, the birds were seen alongside feldegg phenotypes breeding in the same habitats. Females associated with the males appeared similar to feldegg females. In this note, we will refer to this Yellow Wagtail population of unknown identity as "grey-headed" to denote the lack of white supercilium in most birds, and paler head in males compared to black-headed feldegg males.

In May 2018, PA and UO together with Geoff J. Carey, Paul J. Leader and Jonathan Martinez visited Xinjiang, part of the time together with MM and GJ, and observed grey-headed birds that appeared to be breeding (singing, sometimes pairs giving alarm calls) at the following locations (Fig. 1):

- Mosuowan Station for Desert Research $\left(45^{\circ} 01^{\prime} \mathrm{N}\right.$, $\left.86^{\circ} 02^{\prime} \mathrm{E}\right)$.

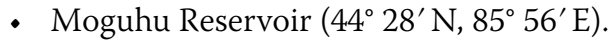

- In vicinity of Shihezi $\left(44^{\circ} 18^{\prime} \mathrm{N}, 86^{\circ} 04^{\prime} \mathrm{E}\right)$.

- In vicinity of Fukang $\left(44^{\circ} 09^{\prime} \mathrm{N}, 87^{\circ} 59^{\prime} \mathrm{E}\right)$.

- Close to the province capital Urumqi $\left(43^{\circ} 49^{\prime} \mathrm{N}, 87^{\circ}\right.$ $\left.37^{\prime} \mathrm{E}\right)$.

Field studies by MM and GJ during the summer months further confirm the presence of breeding grey-headed birds at many of these locations, as well as in the vicinity of Karamay $\left(45^{\circ} 34^{\prime} \mathrm{N}, 84^{\circ} 53^{\prime} \mathrm{E}\right)$. This population has not been described in existing literature (e.g. Ma 2011). The purpose of this paper is to describe its approximate distribution, appearance and vocalisations, and to discuss its taxonomic identity as either an undescribed subspecies or an intergrade form.

\section{Methods}

\section{Morphology and vocalisations}

The descriptions below are based on the field studies conducted in 2011 and 2018, complemented by studies by MM and GJ in other years, as well as on a review of photos online, primarily on the Birds of Xinjiang, China webpage (http://xinjiang.birds.watch/). In total, photos of 92 males and 14 females from Xinjiang in spring and summer (March-August) have been examined (photos and URLs for photos of these birds are found in Additional 
file 1: Figure S1-S67, Additional file 2: Table S1 and Additional file 3: Table S2).

Descriptions of vocalisations are based on recordings made in 2011 and 2018. In total, the recordings contain songs from 16 different males and contact calls from 19 males and three females (URLs can be found in the Additional file 3: Table S3). These recordings were compared with recordings from other taxa (www.xeno-canto. org, www.hbw.com/ibc, www.macaulaylibrary.org, own recordings), and differences in songs were quantified in the software packages Audacity 2.4.2 (Audacity Team) and Raven Lite 2.0 (Cornell Lab of Ornithology), by counting average number of notes per second in sonograms of different taxa.

While a majority of studied grey-headed males can be separated with reasonable certainty from other Yellow Wagtail taxa that occur or could potentially occur in Xinjiang based on a combination of plumage features and vocalisations, as described below, the studied females are very similar to female feldegg. As feldegg breeds in at least western Dzungaria in the same habitats as grey-headed birds, albeit seemingly in lower numbers, there is a small chance that our sampled females might include a few feldegg.

\section{Genetic analysis}

A DNA sample was taken from a freshly dead bird found at Linzhengzi, Fukang, Xinjiang on 12 May 2018 (Additional file 1: Figure S47), where the species appeared to be breeding at high density. Genomic DNA from muscle was extracted using the DNeasy Blood \& Tissue Kit (Qiagen, Hilden, Germany), according to the manufacterer's protocol. The complete mitochondrial nicotinamide adenine dinucleotide dehydrogenase subunit 2 (ND2) was amplified by PCR in a $12.5 \mu \mathrm{L}$ reaction volume consisting of $10 \mu \mathrm{L}$ VWR Red Taq DNA Polymerase Master Mix, $0.5 \mu \mathrm{L}$ of each primer [L5204, Cicero and Johnson (2001); H6313, Johnson and Sorenson (1998)], $1 \mu \mathrm{L}$ deionised $\mathrm{H}_{2} \mathrm{O}$ and $0.5 \mu \mathrm{L}$ of DNA sample, in an Eppendorf autothermal cycler (AG Eppendorf). Cycling conditions were 2 min at $95{ }^{\circ} \mathrm{C}, 40$ cycles of $40 \mathrm{~s}$ at $95^{\circ} \mathrm{C}, 1 \mathrm{~min}$ at $50{ }^{\circ} \mathrm{C}$, and $2 \mathrm{~min}$ at $72{ }^{\circ} \mathrm{C}$, and a final extension of $6 \mathrm{~min}$ at $72{ }^{\circ} \mathrm{C}$. PCR amplicons were then visualised on $1.0 \%$ agarose gels stained with GelRed, and purified by Exonuclease I+ FastAP (Fermentas Life Sciences, Waltham, MA, USA) according to the manufacturer's recommendations. Sequencing of the purified PCR products was performed by GATC Biotech AG (Cologne, Germany), using internal primers L5219 (Sorenson et al. 1999) and H5578 (Cicero and Johnson 2001). This sequence has been deposited in GenBank (accession number OK077986). ND2 sequences of all other Motacilla flava taxa (sensu Alström and Mild 2003) were downloaded from GenBank
(GenBank accession numbers in Fig. 7). Sequences were aligned in SeaView 5.0 (Guoy et al. 2010). The best-fit model for phylogenetic analysis was determined by the Bayesian Information Criterion in jModeltest2 (Darriba et al. 2012). Phylogenetic analysis of the ND2 matrix were run under the best-fit model (HKY + I), a Constant Population Size as well as Yule model (in different analyses), a strict molecular clock (with rate 1.0) and default priors in BEAST 1.10.4 (Drummond et al. 2012). Twenty million generations were run, with trees sampled every 10,000 trees. Convergence to the stationary distribution of the single chains was inspected in Tracer v. 1.7.1 (Rambaut et al. 2014) using a minimum threshold for the effective sample size $(>200)$. The joint likelihood and other parameter values reported large effective sample sizes $(>1000)$, and the trace plot had the shape of a "dense, straight, furry caterpillar". Good mixing of the MCMC and reproducibility were established by multiple runs from independent starting points. The first $20 \%$ of the sampled trees were discarded as burn-in, well after stationarity had been reached, and the posterior probabilities were calculated from the remaining samples. Trees were summarized using TreeAnnotator v. 1.7 (in the BEAST package), choosing "Maximum clade credibility tree" and "Mean heights" and displayed in FigTree 1.4.4 (Rambaut 2018). Both jModeltest and BEAST were run on the CIPRES portal (Miller et al. 2010).

\section{Results \\ Distribution}

Based on our field studies and the reviewed online photos, we assert that the Xinjiang population of greyheaded Yellow Wagtails are summer visitors (arriving in spring from late March) primarily to the belt of cultivated land running from the Urumqi area westwards along the northern slopes of the Tien Shan range and in cultivated areas around Jiyekexiang and Tarbagatay. This pattern is not unexpected given that most of Dzungaria is characterized by an arid climate and saline land. We have also found online photos (http://xinjiang.birds.watch/photos/0034/001/00340043301.jpg and http://xinjiang.birds. watch/photos/0034/001/00340043601.jpg) of two greyheaded birds taken in the Altai City area in the northernmost part of Xinjiang, from where there are also photos of zaissanensis phenotypes with prominent white supercilia. We have found no photos of Yellow Wagtails taken in the arid central parts of the Dzungarian Basin or in Xinjiang south of the Tien Shan range, although presumably, they can occur there during migration. We have found photos (https://birds.kz/v2photo.php?l=en\&s= 039302123) of grey-headed males that closely match the appearance of those breeding in Xinjiang taken in the vicinity of Taldykorgan in eastern Kazakhstan in early 


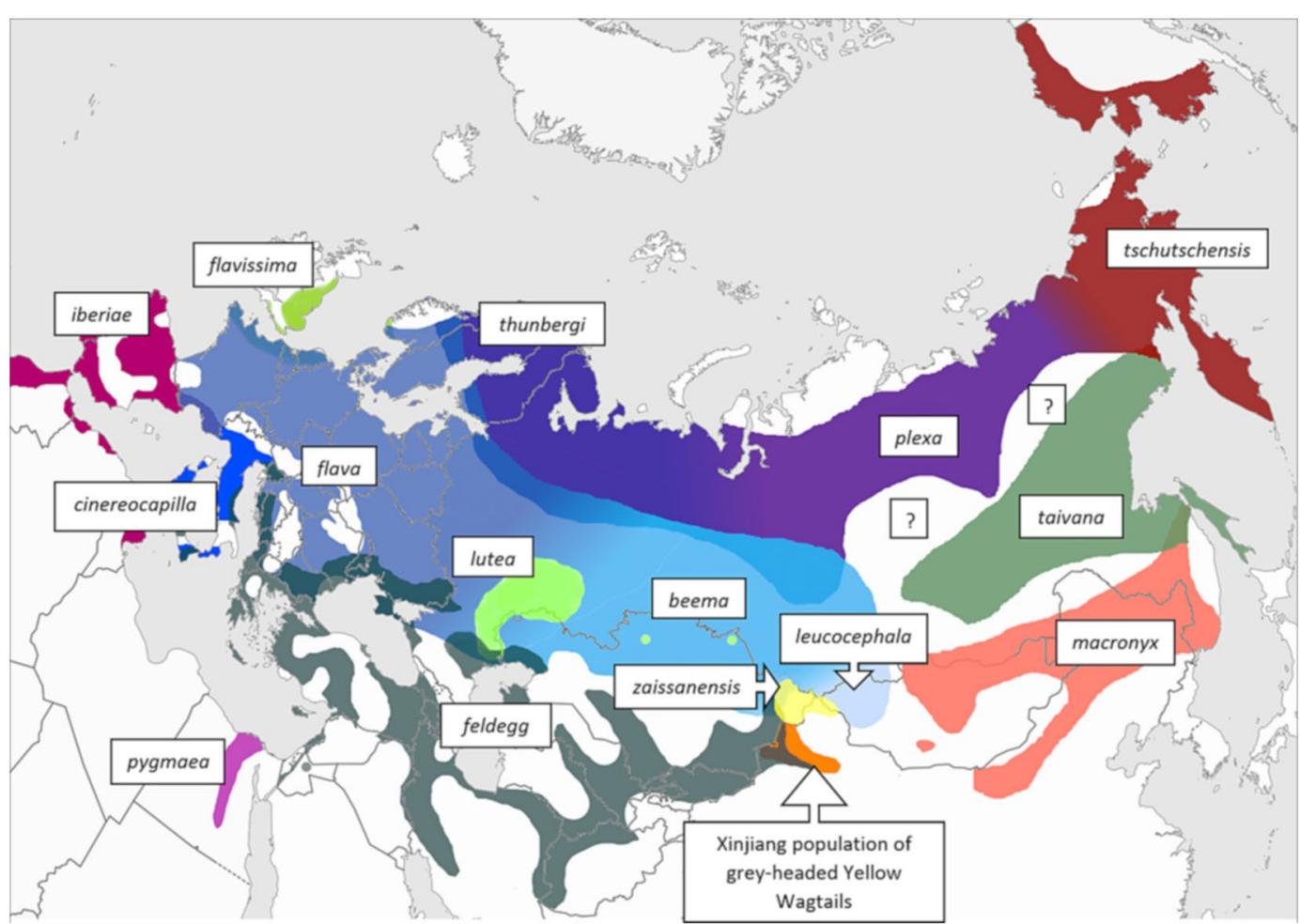

Fig. 2 Approximate breeding ranges of Yellow Wagtail subspecies currently recognized by Gill et al. (2021), as well as those of the disputed form zaissanensis and the population of grey-headed Yellow Wagtails dealt with in this paper. The map draws primarily on distributions given in Alström and Mild (2003), Red'kin et al. (2016), Ferlini (2016), Svensson and Shirihai (2018), Ferlini (2020), Ferlini (2021), Hellquist (2021), and on information provided by Yang Liu, Gombobaatar Sundev and Terry Townshend (in litt.). In many cases, detailed distributions as well as relationships between taxa in areas of contact are still poorly known

April, possibly indicating a westerly migration route and/ or breeding in this area as well. See Fig. 2 for the approximate breeding distribution of grey-headed birds in relation to ranges of the other Yellow Wagtail subspecies recognized by Gill et al. (2021) [following Alström and Mild (2003), with the addition of plexa based on Harris et al. (2018)], as well as zaissanensis (following Hellquist 2021).

\section{Male plumage}

Figure 3 shows examples of grey-headed males. As in other Yellow Wagtail populations, the head pattern is somewhat variable. In the studied photos $(n=92), 75 \%$ of the males lack white supercilium entirely. Many of these show a uniform blue-grey hood, without the contrast between darker ear-coverts and paler crown that is usually, but not always, present in thunbergi (Alström and Mild 2003). Other males are similar to typical thunbergi in this regard. $14 \%$ of the studied males show very short white supercilia, in most cases only a few feathers in front of or/and behind the eye [as is the case also in many thunbergi; Alström and Mild (2003), Hellquist (2021)].
The remaining $11 \%$ show longer supercilia extending both in front of and behind the eye, but still markedly thinner and shorter than in e.g. typical M. f. flava and $M$. f. beema (hereafter flava and beema, respectively), or in most zaissanensis phenotypes breeding in the Altai.

Eighty-one percent of the studied males show clean yellow breasts without dark spotting. In this regard, they are similar to southern Yellow Wagtail subspecies, including cinereocapilla, feldegg, beema and macronyx (Alström and Mild 2003). By comparison, a majority of European thunbergi and dark-headed birds breeding in the Siberian Arctic show dark markings on the breast [Alström and Mild (2003), Hellquist (2021); the taxonomic position of Siberian dark-headed birds is disputed; they are synonymised with thunbergi by Alström and Mild (2003) but separated as M. f. "plexa"-hereafter plexa-by e.g. Harris et al. (2018); see also Pavlova et al. (2003); Red'kin et al. (2016); Drovetski et al. (2018); Hellquist (2021)]. Eighteen percent of the studied males show a few dark spots on the upper breast, while only one male in the sample (1.3\%) shows extensive spotting like many European thunbergi and Siberian dark-headed birds. 

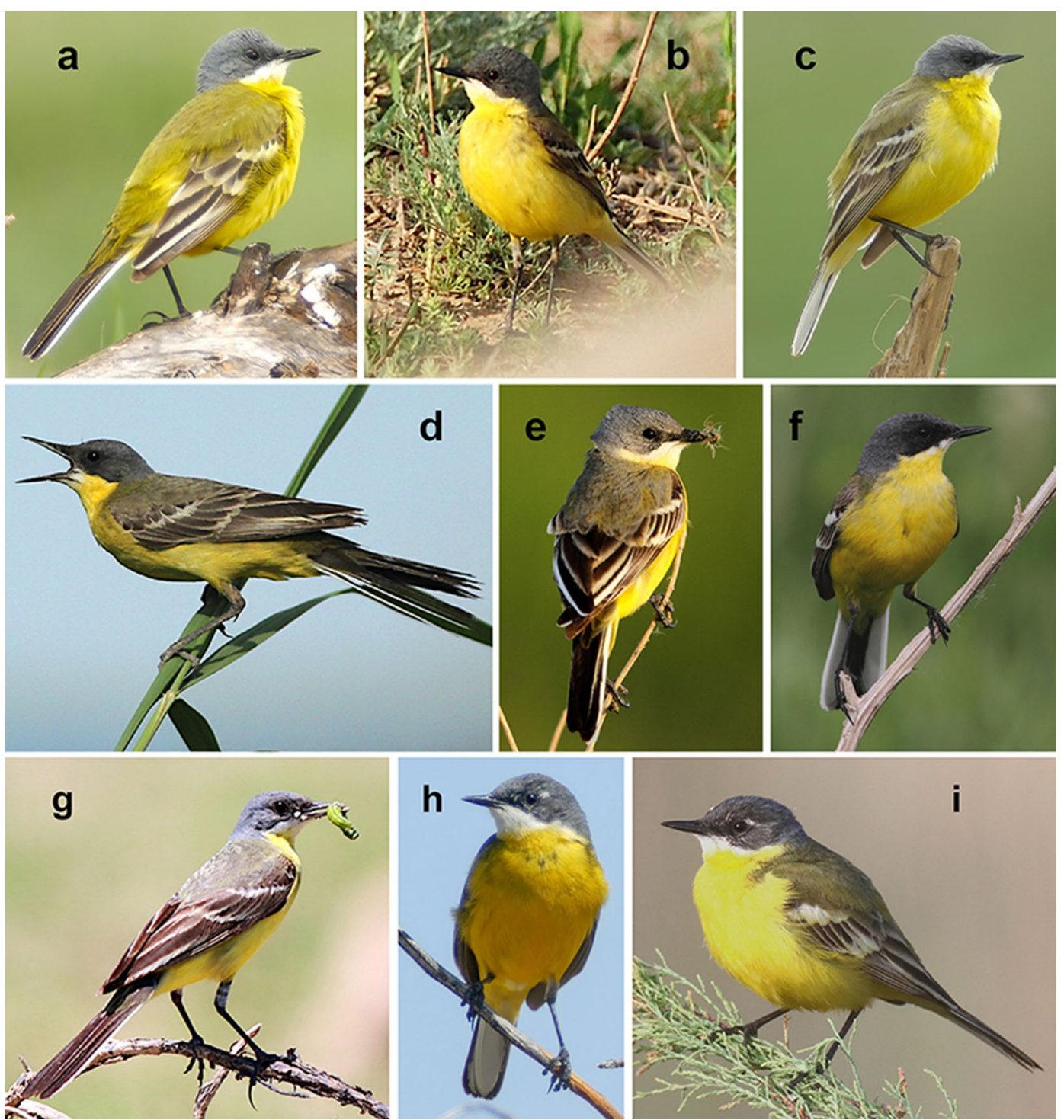

Fig. 3 Variation in male plumage in grey-headed Yellow Wagtails breeding in Xinjiang. Note bluish grey crown and lack of supercilium in a-g, and clean yellow breast and extensive white on throat in most birds. $\mathbf{g}$ depicts a breeding bird carrying food to nestlings, while the bird in e carries nest material. $\mathbf{h}$-i illustrate the minority of males in the studied sample that show short supercilia, approaching appearance of some M. f. zaissanensis, cf. Figure 9b. a Mogohu Lake, 15 May 2018 (Per Alström). b Jiyekexiang, 16 May 2011 (Petter Haldén). c Moguhu Lake, 15 May 2018 (Per Alström) d Fukang, 29 June 2019 (Ming Ma). e Shihezi, 10 May 2010 (Jie Xu).f Shihezi, 10 May 2010 (Jie Xu). g Fukang, 22 June 2016 (Ming Ma). h Urumqi 11 May 2018 (Per Alström). i Fukang, 12 May 2018 (Jonathan Martinez)

On average, the grey-headed males show considerably more white on the throat than typical thunbergi, beema, feldegg and macronyx, i.e. they are more similar to cinereocapilla in this regard (cf. Alström and Mild 2003). In $39 \%$, more than half of the throat is white; $59 \%$ show conspicuous white below the bill covering less than half of the throat, while only two individuals in the sample (2.2\%) show entirely yellow throat (at most a few white feathers at bill base).

\section{Female plumage}

Studied females are very similar to female feldegg, with rather pale greyish upperparts and mostly white underparts with reduced amounts of yellow, poorly defined dark loral stripe, weak or no supercilium and in several birds a nearly unbroken white eye-ring (two examples in Fig. 4). Three of the 14 females in the sample show more extensive yellow, covering most of the underparts, just as in some feldegg females (Alström and Mild 

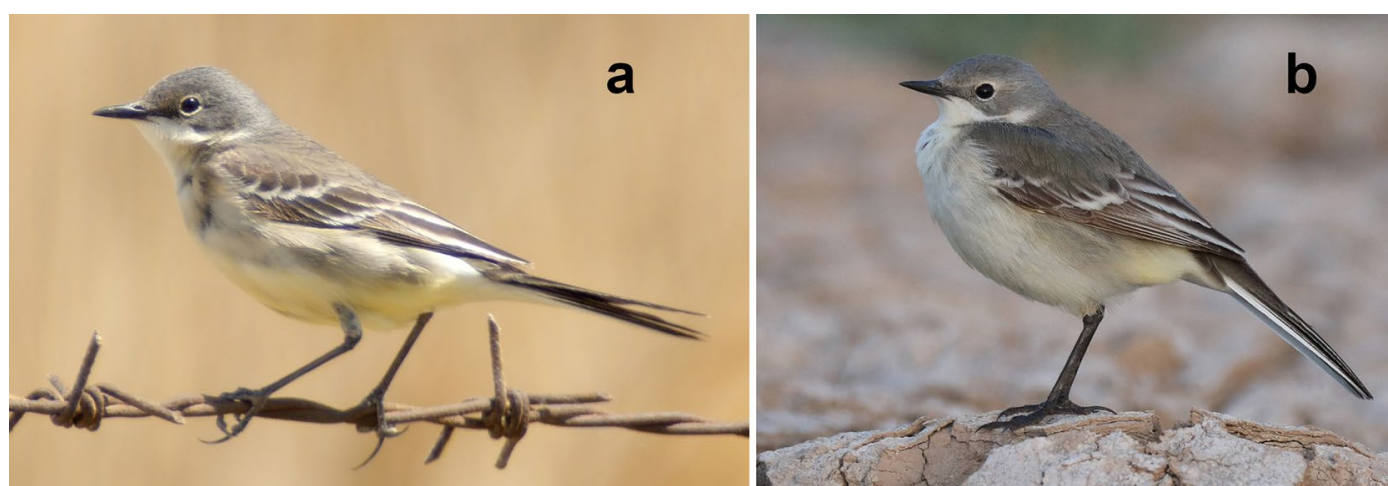

Fig. 4 Females photographed in proximity to grey-headed males. Note greyish appearance with limited supercilium, very similar to M. f. feldegg females. a Urumqi, 11 May 2018 (Per Alström). b Fukang, 22 May 2018 (Jonathan Martinez)

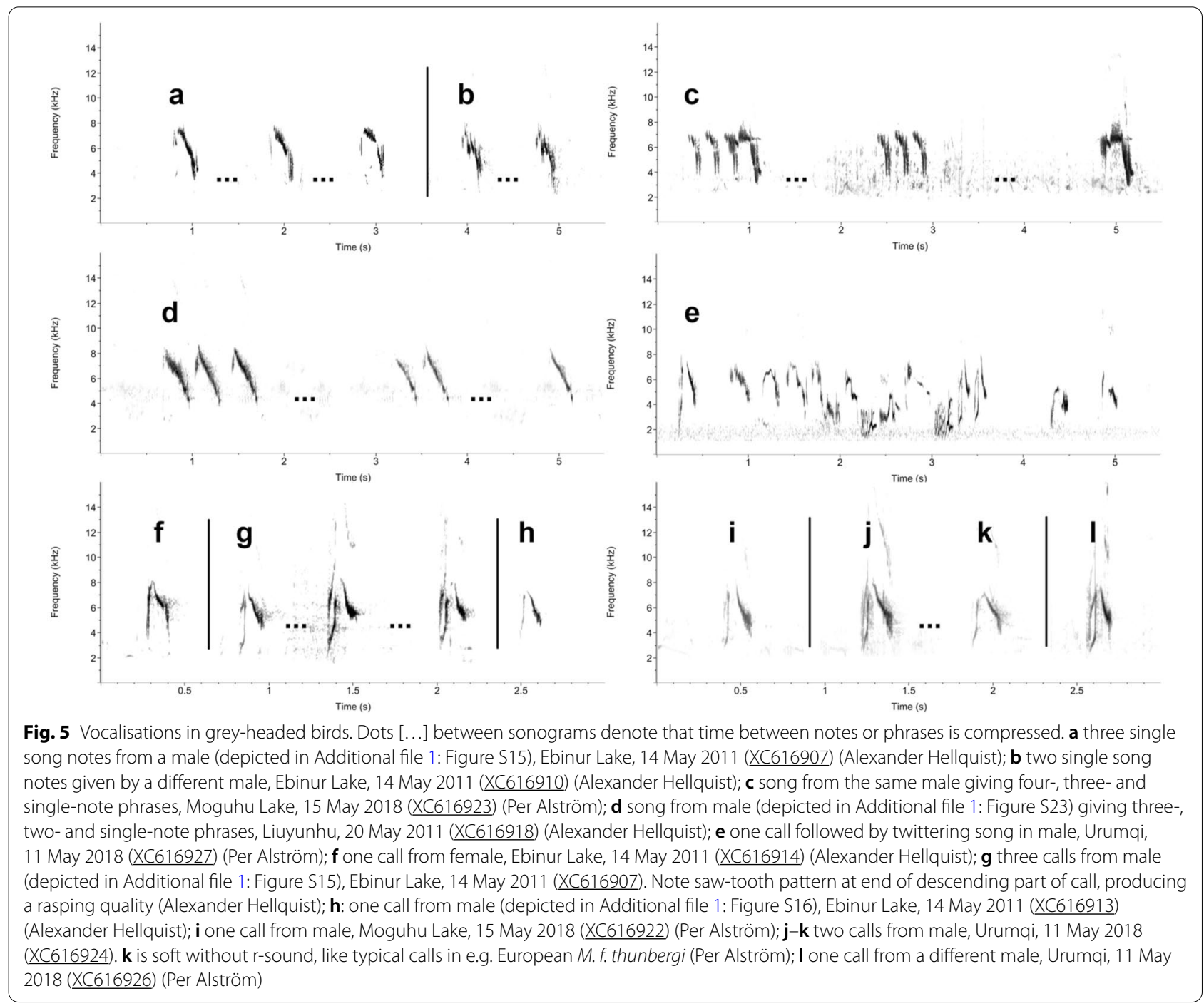


2003), but the colour is still pale and the upper breast and throat are whitish.

\section{Song}

The 13 singing males that were recorded all gave single rasping song notes, similar to typical songs in western Yellow Wagtail subspecies, e.g. flava, feldegg, beema, cinereocapilla and European thunbergi [Fig. 5a-b; cf. sonograms in Alström and Mild (2003) and Hellquist (2021)]. Nine of the males also gave song phrases consisting of 2-4 repeated notes (Fig. 5c-d). The pace of this "fast song type" is similar to that of western Yellow Wagtail subspecies [see sonograms in Alström and Mild (2003)], being slower than in populations breeding in eastern Arctic Siberia (M. f. tschutschensis; hereafter tschutschensis) and in macronyx (Fig. 6) (Hellquist 2021). In one bird, a fast twittering song type was recorded along with single rasping notes (Fig. 5e). Several males also gave series of chirping notes and notes reminiscent of contact calls that might function either as alarm calls or a (relaxed) song. Such series can be heard also in other Yellow Wagtail populations.

\section{Calls}

The recorded contact calls are reminiscent of those of northwestern Yellow Wagtail subspecies, e.g. flava, thunbergi and beema [see sonograms in Alström and Mild (2003)]. In most cases, there is a discernable r-sound at the very end of the call, giving it a slightly rasping quality following the soft onset. In sonograms (Fig. $5 f-j, 1$ ), this is visible as a saw-tooth pattern at the end of the descending part of the call. In this respect, the calls are similar to some calls of beema and feldegg, although typical feldegg calls are even more rasping [see sonograms in Alström and Mild (2003)]. A few calls from the Xinjiang birds lack the r-sound entirely, as typical calls in European thunbergi (Fig. 5k). All calls are less sharp than the Citrine Wagtail Motacilla citreola-like typical calls given by Arctic grey-headed birds east from Taimyr (plexa; see Hellquist 2021) and by the eastern taxa tschutschensis, $M$. f. taivana and macronyx (Alström and Mild 2003).

\section{DNA}

A total of $1041 \mathrm{bp}$ were obtained for the mitochondrial ND2 gene. The ND2 tree shows the single sample from Xinjiang to be nested in the clade of western taxa, with posterior probability 1.00 (Fig. 7).

\section{Discussion}

Males of grey-headed Yellow Wagtails breeding in Xinjiang Uygur Autonomous Region, China are closely similar in plumage to the widely disjunct cinereocapilla, pygmaea, thunbergi, plexa and macronyx, whereas females resemble females of the marginally sympatric feldegg (Fig. 4). The songs agree with those of western M. flava taxa but differ from eastern $M$. flava taxa, whereas the calls are rather similar to those of northwestern $M$. flava taxa, but not to the typical calls of southwestern (including feldegg and cinereocapilla) and eastern (including plexa and macronyx) ones (Alström and Mild 2003; Hellquist 2021). Mitochondrial DNA places the single

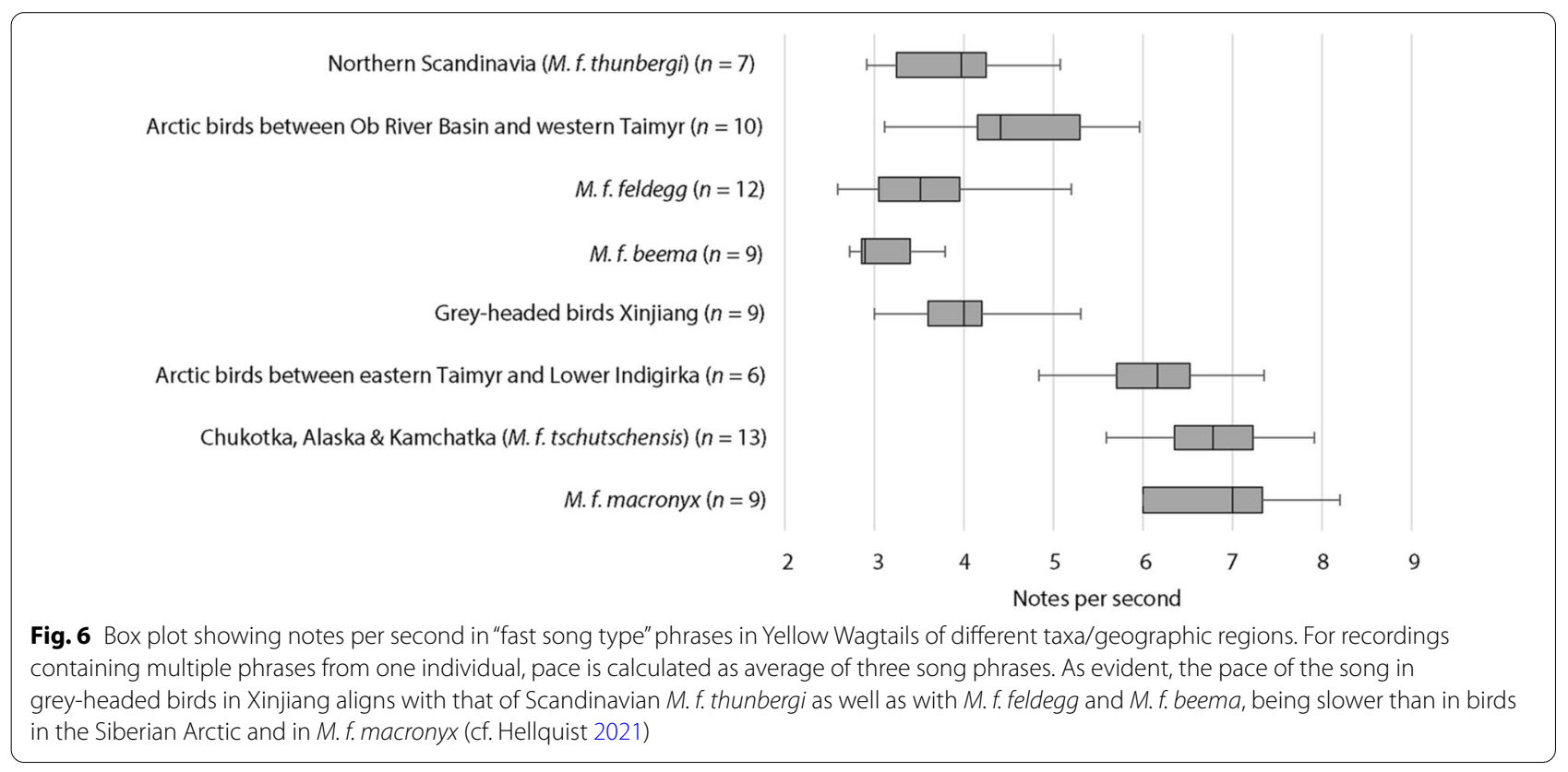




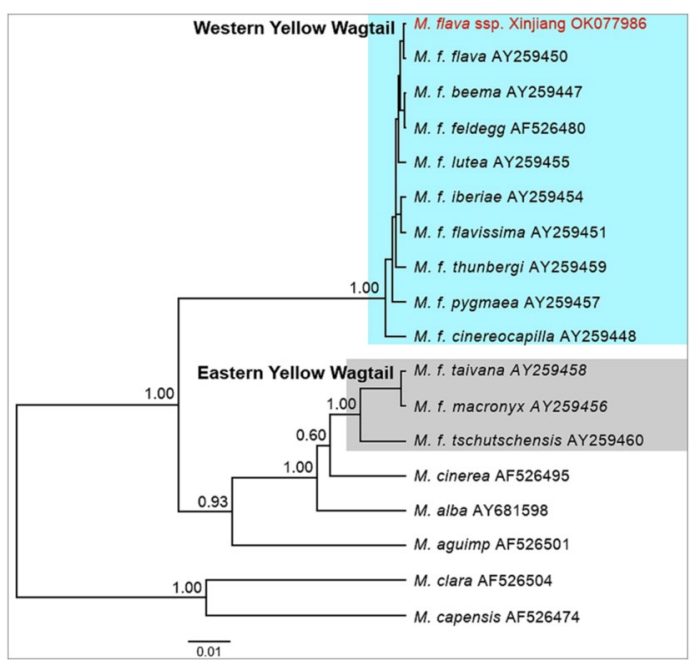

Fig. 7 Mitochondrial ND2 tree including all taxa in the Motacilla flava complex sensu Alström \& Mild (2003), with the Xinjiang sample highlighted in red in the Western Yellow Wagtail clade. Note that the mitochondrial tree does not represent the true species phylogeny of Motacilla (cf. Harris et al. 2018)

sequenced Xinjiang bird in the western clade. Two possibilities may be considered regarding the taxonomic status of the Xinjiang population of grey-headed birds:

1. They are the result of interbreeding between adjacent taxa.

2. They deserve recognition as a separate, as yet undescribed, subspecies.

Regarding the first possibility, taxa breeding in proximity to the grey-headed birds, thus constituting potential sources of intergradation, are feldegg, beema and zaissanensis, with at least feldegg even occurring in sympatry with grey-headed birds in some locations in western Dzungaria at least east to Shihezi (observations by PA and GJ). The taxon beema breeds in eastern Kazakstan and southern Siberia (Alström and Mild 2003) while zaissanensis breeds in the Altai Mountains of China, Kazakstan and possibly Russia and Mongolia (Hellquist 2021).

Although the grey-headed males are clearly different from feldegg, beema and zaissanensis, they have some features in common with these, including clean yellow breasts, and contact calls that are similar to those of beema and zaissanensis as well as many softer calls of feldegg (cf. Alström and Mild 2003; Hellquist 2021). They show more white on the throat than typical beema and feldegg, although some beema and feldegg also show quite extensive white throats [more commonly in the eastern part of the range of feldegg; Alström and Mild (2003)]. According to Alström and Mild (2003), some intergrades between feldegg and flava are similar to cinereocapilla, which in turn is similar to the Xinjiang birds. Presumably, the same can be true for intergrades between feldegg and beema, considering the great similarity between beema and flava. A few odd phenotypes were observed in the same localities as territorial grey-headed birds in 2011, including one "pseudo-feldegg" showing mostly black heads but greyish napes (Fig. 8a) and one "superciliaris" with a largely blackish head with a whitish supercilium (Fig. 8b) (these are not included in the analysis of male plumage above). These birds indicate that feldegg at the eastern limit of its range might be subject to introgression from the population of grey-headed birds, from beema or from zaissanensis. Ferlini (2016) demonstrates how feldegg has expanded in Central Asia over the last centuries as deserts have been turned into arable land, which might increase potential for interbreeding with other taxa, even though he finds no evidence for changes in the distribution at the very eastern edge of the range,
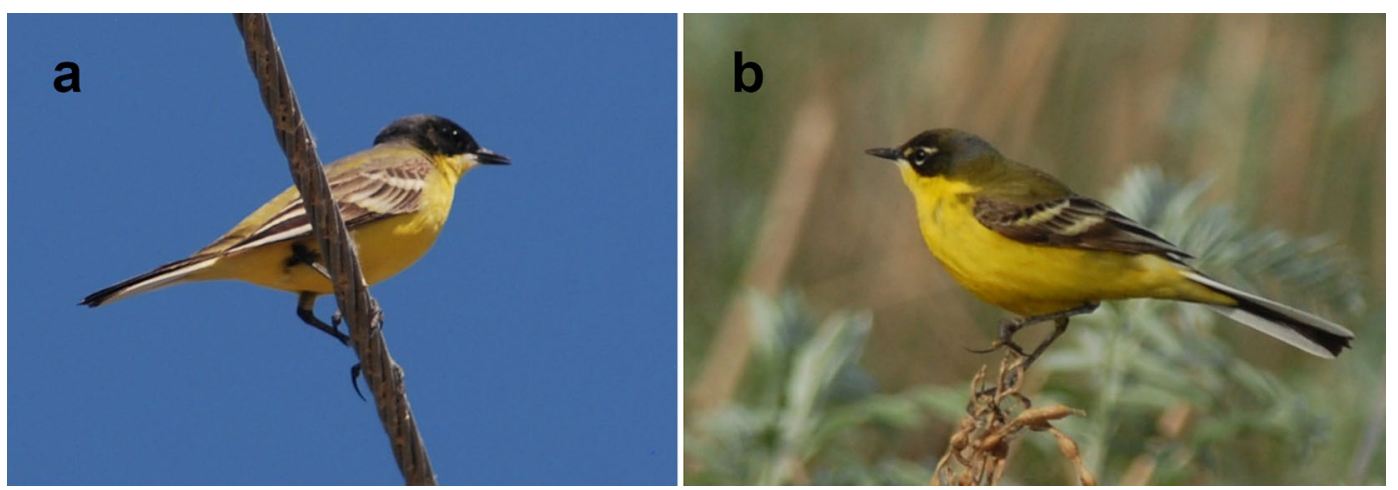

Fig. 8 Examples of odd male M. flava phenotypes observed in westernmost Xinjiang in 2011. The bird in a shows a plumage consistent with $M$. f. feldegg, save for a greyish nape that might indicate introgression with grey-headed populations. The bird in $\mathbf{b}$ shows a similar plumage but also white supercilium (matching form "superciliaris"). a Ebinur Lake, 14 May 2011 (Alexander Hellquist). b Jiyekexiang, 15 May 2011 (Petter Haldén) 

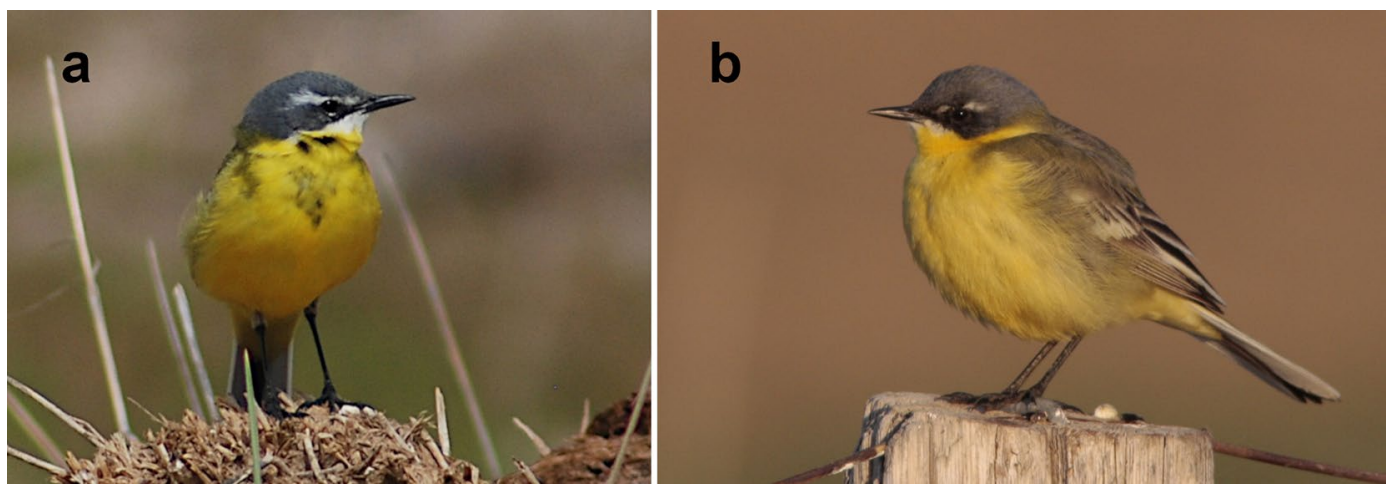

Fig. 9 M. f. zaissanensis males. The bird in a has a typical plumage shown by most studied males in this population, while the bird in $\mathbf{b}$ has a rather poorly developed white supercilium. a Kalawu Tekele Lake, 19 May 2011 (Alexander Hellquist). b Kalawu Tekele Lake, 19 May 2011 (Peter Schmidt)

i.e. western Xinjiang, from the late nineteenth century and onwards. The small proportion of grey-headed birds in the studied material showing a thin supercilium could be a sign of influence from beema or zaissanensis, while, conversely, one male among the breeding zaissanensis studied in the Chinese Altai in 2011 showing a weak supercilium could indicate introgression from greyheaded birds (Fig. 9b). Further research in these areas would be of interest, as well as in adjacent parts in e.g. easternmost Kazakhstan where it seems likely that greyheaded birds also occur.

In support of the hypothesis that the grey-headed birds constitute an undescribed subspecies, the majority of the males show a distinct and consistent head pattern, which does not match that of any other taxon breeding nearby. The variability in the plumage seems comparable to that of other Yellow Wagtail subspecies. Moreover, grey-headed birds appear to have a discrete breeding area where other breeding phenotypes are rare or absent, save for the westernmost part where feldegg also occurs. It could also be argued that the geographic position of the breeding area is somewhat odd if grey-headed birds would constitute intergrades between two or more taxa. While some localities, e.g. around Tarbagatay, lie in between the ranges of feldegg and zaissanensis, no Yellow Wagtails are known to breed directly east of the breeding sites of grey-headed birds around Urumqi. These sites are thus not located in between known distributions of other Yellow Wagtails, making the intergradation hypothesis seem less likely. However, the ranges of these taxa have surely shifted over time as a result of, e.g., glacial periods, so it is possible that past distributions were more in agreement with expectations from an introgression scenario.

Looking farther east, there are two Yellow Wagtail taxa breeding at roughly the same latitudes as the grey-headed birds in Xinjiang: M. f. leucocephala (hereafter leucocephala) and macronyx (Fig. 2). According to the literature (e.g. Alström and Mild 2003), leucocephala breeds in northwestern Mongolia and adjacent parts of Russia. Based on current knowledge, the ranges of leucocephala and the grey-headed birds in Xinjiang are thus not adjacent but separated by the range of zaissanensis. The taxon macronyx breeds in Mongolia, northeastern China and the Russian Amur region. It is overall very similar to the grey-headed Xinjiang birds, but it shows on average less white on the throat in males, and has different song and call, and a more male-like female plumage (Alström and Mild 2003; Hellquist 2021). Moreover, the mitochondrial ND2 sequence from the sampled grey-headed Xinjiang bird supports that it belongs in the western group of Yellow Wagtails and not in the eastern group where macronyx belongs (cf. Ödeen and Alström 2001; Alström and Ödeen 2002; Voelker 2002; Ödeen and Björklund 2003; Pavlova et al. 2003; Drovetski et al. 2018; Harris et al. 2018).

\section{Conclusions}

To conclude, in our opinion, the grey-headed birds breeding in Xinjiang Uygur Autonomous Region, China most likely represent an undescribed Yellow Wagtail subspecies. However, more research is needed to firmly establish their relationships with other populations and to gain a better understanding of their distribution and biology.

\section{Supplementary Information}

The online version contains supplementary material available at https://doi. org/10.1186/s40657-021-00289-y.

Additional file 1: Figure S1-S67. Photos of 67 grey-headed Yellow Wagtails taken in Xinjiang and included in the analysis of plumage. 
Additional file 2: Table S1. Data on photos in Figure S1-S67.

Additional file 3: Table S2. URLs for photos of 39 grey-headed Yellow Wagtails in Xinjiang published online and included in the analysis of plumage. Table S3. URLs for recordings of 25 grey-headed Yellow Wagtails in Xinjiang published online and included in the analysis of vocalisations.

\section{Acknowledgements}

We are grateful to Meng Chao, Lianfu Gu, Jonathan Martinez, Wen Ming, Bo Ning, Jian Peng, Congda Wang, Yong Xia, Jie Xu, Bo Zhao and Yuehui Zhao for allowing us to use their photos, and to Yang Liu, Gombobaatar Sundev and Terry Townshend for providing information about the distribution of discussed forms.

\section{Authors' contributions}

All authors took part in the field work. AH conducted the analysis of morphology and vocalizations. UO and PA conducted the genetic analysis. AH drafted the manuscript and all other authors helped to revise it. All authors read and approved the final manuscript.

\section{Funding}

PA gratefully acknowledges support from Jornvall Foundation and the Swedish Research Council (grant No. 2015-04402).

\section{Availability of data and materials}

Photos and URLs for photos and URLs for sound recordings of birds included in the analyses of plumage and vocalisations are available in additional files. Other data used in the study are available from one of the corresponding authors $(\mathrm{AH})$ on request.

\section{Declarations}

Ethics approval and consent to participate Not applicable.

\section{Consent for publication}

Not applicable.

\section{Competing interests}

The authors declare that they have no competing interests.

\section{Author details}

${ }^{1}$ Fatburs kvarngata 17, 11864 Stockholm, Sweden. ${ }^{2}$ Xinjiang Institute of Ecology and Geography, Chinese Academy of Sciences, No. 818 Beijing Road, Urumqi 830011, Xinjiang, China. ${ }^{3}$ Xinjiang Birdwatching Society, 311 Nongda East Road, Urumqi 830091, Xinjiang, China. ${ }^{4}$ Systematics and Biodiversity, Department of Biology and Environmental Sciences, University of Gothenburg, Göteborg, Sweden. ${ }^{5}$ Gothenburg Global Biodiversity Centre, Gothenburg, Sweden. ${ }^{6}$ Animal Ecology, Department of Ecology and Genetics, Evolutionary Biology Centre, Uppsala University, Norbyvägen 18D, 752 36 Uppsala, Sweden. ${ }^{7}$ Key Laboratory of Zoological Systematics and Evolution, Institute of Zoology, Chinese Academy of Sciences, Beijing 100101, China. ${ }^{8}$ Edeby 9, 74191 Knivsta, Sweden. ${ }^{9}$ Lenabergsvägen 33, 74392 Vattholma, Sweden. ${ }^{10}$ Tallmovägen 9, 75645 Uppsala, Sweden.

Received: 16 May 2021 Accepted: 18 October 2021

Published online: 23 October 2021

\section{References}

Alström P, Mild K. Pipits and wagtails. Princeton: Princeton University Press; 2003

Alström P, Ödeen A. Incongruence between mitochondrial DNA, nuclear DNA and nonmolecular data in the avian genus Motacilla: implications for estimates of species phylogenies. In: Alström P, editor. Species limits and systematics in some passerine birds. Uppsala: Acta Universitatis Upsaliensis; 2002

Cicero C, Johnson NK. Higher-level phylogeny of New World vireos (Aves: Vireonidae) based on sequences of multiple mitochondrial DNA genes. Mol Phylogenet Evol. 2001;20:27-40.

Darriba D, Taboada GL, Doallo R, Posada D. jModelTest 2: more models, new heuristics and parallel computing. Nat Methods. 2012;9:772.

del Hoyo J, Collar N. HBW and BirdLife international illustrated checklist of the birds of the world. Volume 2: Passerines. Barcelona: Lynx Edicions and BirdLife International; 2016.

Drovetski SV, Reeves AB, Red'kin YA, Fadeev IV, Koblik EA, Sotnikov VN, et al. Multi-locus reassessment of a striking discord between mtDNA gene trees and taxonomy across two congeneric species complexes. Mol Phylogenet Evol. 2018;120:43-52.

Drummond AJ, Suchard MA, Xie D, Rambaut A. Bayesian phylogenetics with BEAUti and the BEAST 1.7. Mol Biol Evol. 2012;29:1969-73.

Ferlini F. Evolution of the breeding range of the Black-headed Yellow Wagtail (Motacilla flava feldegg). Riv Ital Ornitol. 2016:86:3-38.

Ferlini F. The Gmelin's wagtail Motacilla lutea: breeding range, migratory movements and wintering range. Riv Ital Ornitol. 2020;90:3-50.

Ferlini F. The White-headed yellow wagtail Motacilla flava leucocephala (Przewalski, 1887): migration, movements, and breeding and wintering ranges. Riv Ital Ornitol. 2021;91:3-26.

Gill F, Donsker D, Rasmussen P, editors. IOC World Bird List version 11.1; 2021. https://doi.org/10.14344/IOC.ML.11.1.

Gouy M, Guindon S, Gascuel O. SeaView Version 4: A multiplatform graphical user interface for sequence alignment and phylogenetic tree building. Mol Biol Evol. 2010;27:221-4.

Harris RB, Alström P, Ödeen A, Leaché AD. Discordance between genomic divergence and phenotypic variation in a rapidly evolving avian genus (Motacilla). Mol Phylogenet Evol. 2018;120:1-26.

Hellquist A. Identification and taxonomy of northern and eastern Yellow Wagtails—new pieces to the puzzle. Dutch Birding. 2021;43:333-70.

Johnson KP, Sorenson MD. Comparing molecular evolution in two mitochondrial protein coding genes (cytochrome b and ND2) in the dabbling ducks (tribe: Anatini). Mol Phylogenet Evol. 1998;10:82-94.

Ma M. A checklist on the distribution of the birds in Xinjiang. Beijing: Science Press; 2011.

Miller MA, Pfeiffer W, Schwartz T. Creating the CIPRES Science Gateway for inference of large phylogenetic trees. In: 2010 gateway computing environment workshop; 2010

Ödeen A, Alström P. Evolution of secondary sexual traits in wagtails (genus Motacilla). In: Ödeen A, editor. Effects of post-glacial range expansions and population bottlenecks on species richness. Uppsala: Acta Universitatis Upsaliensis; 2001.

Ödeen A, Björklund M. Dynamics in the evolution of sexual traits: losses and gains, radiation and convergence in yellow wagtails (Motacilla flava). Mol Ecol. 2003;12:2113-30.

Pavlova A, Zink RM, Drovetski SV, Red'kin Y, Rohwer S. Phylogeographic patterns in Motacilla flava and Motacilla citreola: species limits and population history. Auk. 2003;120:744-58.

Rambaut A. FigTree version 1.4.4. 2018. http://tree.bio.ed.ac.uk/software/figtr ee.

Rambaut A, Suchard MA, Xie D, Drummond AJ. Tracer version 1.6. 2014. http:// beast.bio.ed.ac.uk/Tracer.

Red'kin YA, Arkhipov VY, Volkov SV, Mosalov AA, Koblik EA. Art oder keine Art? Strittige taxonomische Ansichten zu den Vogeln Nord-Eurasiens. Ornithol Mitt. 2016:68:327-54

Shirihai H, Svensson L. Handbook of Western Palearctic birds: passerines. London: Christopher Helm Publishers Limited; 2018.

Sorenson MD, Ast JC, Dimcheff DE, Yuri T, Mindell DP. Primers for a PCR-based approach to mitochondrial genome sequencing in birds and other vertebrates. Mol Phylogenet Evol. 1999;12:105-14.

Voelker G. Systematics and historical biogeography of wagtails: dispersal versus vicariance revisited. Condor. 2002;104:725-39. 